Ushchapovskyi A., Ivchuk $\mathbf{N}$.

\title{
USE OF SEMI-FINISHED CHERRY-BEET PUREE IN TECHNOLOGY OF SWEET DISHES AND DESSERTS
}

Солодкі страви та десерти користуються підвищеним попитом у споживача. Проте дана продукція, як правило, має незбалансований хімічний склад, високу калорійність, значний вміст жсрів $і$ вуглеводів, відносно низький вміст білку та недостатню кількість біологічно активних речовин. Джерелом природних біологічно активних речовин (БАР) є пюре, соки, екстракти, підварки з плодів, овочів, культурних та дикорослих ягід, лікарських трав тощо. Тому важливим питанням на сьогодні, для даного виду продукції, $\epsilon$ вдосконалення рещептури існуючого асортименту солодких страв за рахунок використання натуральних рослинних компонентів підвищеної біологічної иінності. Таким чином, об'єктом дослідження є технологія десерту оздоровчого призначення на основі вишнево-бурякового пюре-напівфабрикату та його вплив на структурно-механічні, фізико-хімічні й органолептичні показники готових виробів.

У роботі використано стандартні методики досліджень згідно вимог нормативної документації. Дослідження вмісту бетаніну проводили спектрофотометричним методом. Антиоксидантну активність визначали методом бромної кулонометрії. Органолептичні та фізико-хімічні показники готової страви визначали у відповідності до ДСТУ 3718:2007 «Солодкі страви, желе, муси, пудинги, концентрати молочні».

Для збагачення солодких страв та десертів при створенні оздоровчих та функціональних харчових продуктів пропонується використовувати пюре-напівфабрикат, до складу якого входить пюре з вишні та пюре з буряку столового (співвідношення 2:1). Встановлена можливість покращення органолептичних, фізико-хімічних та структурно-механічних показників готових виробів за рахунок використання композиційного поєднання вишнево-бурякового пюре-напівфабрикату та желатину у кількості 3 \%. Розроблено технологію десерту оздоровчого призначення, досліджено його якість за органолептичними та фізико-хімічними показниками, вмістом біологічно активних $і$ поживних речовин. Наявність значної кількості біологічно активних речовин, які володіють антиоксидантними властивостями, забезпечують оздоровчу та профілактичну дію десерту. Розроблений десерт рекомендований для виробництва у закладах ресторанного господарства.

Ключові слова: солодкі страви, оздоровчий продукт, вишнево-буряковий пюре-напівфабрикат, біологічно активні речовини, органолептичні показники, фізико-хімічні показники.

\section{Introduction}

The deterioration of the environmental situation in the world, rapid changes in the modern pace of life and unbalanced nutrition lead to an unsatisfactory state of public health. The consequence of these processes is the depletion of the adaptive capabilities of the body and the emergence of a wide range of nutritional-dependent diseases. Therefore, today there is a problem of deficiency in the intake of certain biologically active substances in the human body.

One of the priority areas for the development of the food industry at the present stage is the development and implementation of new and improvement of existing production technologies in order to create health-improving and functional products [1]. Given the current trends in the food market, scientists and food manufacturers are faced with the problem of expanding the product range of products by including functional ingredients in traditional recipes. Recently, sweet dishes and desserts are in high demand among consumers. However, these products are usually unbalanced chemical composition, high calorie content. A significant content of fats and carbohydrates, a relatively low protein content and an insufficient amount of biologically active substances found in sweet foods provide the human body with only negative effects [2]. Therefore, today, for this type of product, an urgent issue is improving the formulation of the existing assortment of sweet dishes through the use of natural plant components, of increased biological value.

The source of natural biologically active substances (BAS) is mashed potatoes, juices, extracts, preparations from fruits, vegetables, cultivated and wild berries, medicinal herbs and the like. The issues of scientific substantiation and development of prescription compositions, ensuring the healing properties of sweet dishes and desserts using natural raw materials with a high content of biologically active substances are of particular importance for further scientific research [3-5]. Significant attention is focused on solving the structural, rheological and organoleptic properties of dessert products, as well as competitiveness 
and economic efficiency from the implementation of developed technologies in restaurant establishments [6-8].

Thus, the object of research is the technology of a dessert for health purposes based on cherry-beetroot puree and a semi-finished product and its effect on the structural, mechanical, physico-chemical and organoleptic characteristics of finished products. For the production of semi-finished cherry-beet puree, beetroots of the Bordeaux variety and Volodymyrska cherries were selected. Semi-finished puree was obtained according to the developed method [9]. The aim of research is to justify the prospects of using semi-finished cherry-beetroot puree product in the technology of sweet dishes and desserts with a high content of biologically active substances for restaurant establishments.

\section{Methods of research}

The study of the nutritional and biological value of raw materials and finished products, as well as their organoleptic characteristics, was carried out according to standard methods in accordance with the requirements of regulatory documents:

- solids and moisture content in raw materials ac-

cording to GOST 28561-90;

- mass fraction of titratable acids (in terms of malic acid) - by volume titration method according to DSTU EN 12147-2003;

- active acidity $(\mathrm{pH})$ was determined using a $\mathrm{pH}$ meter according to GOST 26188-84;

- total content of phenolic substances - by the FolinCiocalteu method in terms of gallic acid according to DSTU 3845-99;

- vitamin C content - by iodometric method according to GOST 245556-89;

- content of pectin substances - titrimetric method according to DSTU 8069:2015;

- organoleptic evaluation of finished products DSTU 3718:2007.

The study of the betanine content was carried out by spectrophotometric method.

The absorption of light was measured at wavelengths of $538 \mathrm{~nm}$ and $476 \mathrm{~nm}$, which corresponds to the absorption maximum for betanine (red beet beta) and Volga xanthin-I (red beet beta).

The total concentration of betalaines was expressed as the sum of the concentrations of betacyans and betaxanthine [10].

Bromine antioxidant activity was determined by coulometric titration with bromine of the studied samples. The bromine antioxidant ability (AOA) was calculated in coulomb (C) per $100 \mathrm{~g}$ of raw material and ready-to-cook semi-finished puree [11].

The organoleptic and physico-chemical characteristics of the finished dessert were determined in accordance with DSTU 3718:2007 «Sweet foods, jellies, mousses, puddings, milk concentrates».

\section{Research results and discussion}

To enrich sweet dishes and desserts when creating healthy and functional food products, it is proposed to use mashed semi-finished product, which includes mashed cherry and mashed beetroot (2:1 ratio).

To obtain semi-finished cherry-beetroot puree, use fresh berries of the Volodymyrska cherries and pre-boiled root crops of the Bordeaux table beet [12].
To obtain a ready-made dessert with high quality indicators and a high content of biologically active substances, it is proposed to first study the physicochemical parameters of semi-finished cherry-beetroot puree, the determination results of which are given in Table 1.

Table 1

Physico-chemical characteristics of semi-finished cherry-beetroot puree

\begin{tabular}{|l|c|}
\hline \multicolumn{1}{|c|}{ Index } & $\begin{array}{c}\text { Mashed semi-finished } \\
\text { product }\end{array}$ \\
\hline Humidity, \% & $76.4 \pm 0.9$ \\
\hline Active acidity, $\mathrm{pH}$ & $3.9 \pm 0.2$ \\
\hline Titratable acidity (in terms of malic acid), \% & $1.38 \pm 0.1$ \\
\hline Bromic ADA, C/100 g & 184.2 \\
\hline Solids content, \% & $22.1 \pm 0.6$ \\
\hline Pectin substances content, g & $0.95 \pm 0.2$ \\
\hline
\end{tabular}

To obtain a dessert with a high content of biologically active substances, the content of anthocyanins, phenolic compounds and betalaines in semi-finished cherry-beetroot puree shown in Table 2 is studied.

Table 2

The biochemical composition of semi-finished cherry-beetroot puree

\begin{tabular}{|c|c|c|c|}
\hline Raw materials & $\begin{array}{c}\text { The total content of phe- } \\
\text { nolic compounds, mg in } \\
\text { terms of gallic acid/100 g } \\
\text { of raw material }\end{array}$ & $\begin{array}{c}\text { The total } \\
\text { content of } \\
\text { anthocyanins, } \\
\text { mg/100 g }\end{array}$ & $\begin{array}{c}\text { The } \\
\text { content of } \\
\text { betanine, } \\
\text { mg/100 g }\end{array}$ \\
\hline $\begin{array}{c}\text { Semi-finished } \\
\text { cherry-beetroot } \\
\text { puree }\end{array}$ & 472 & 750 & 45 \\
\hline
\end{tabular}

According to the results of the studies given in Table 1 and Table 2, it is possible to conclude that semi-finished cherry-beetroot puree has satisfactory physico-chemical characteristics, high antioxidant activity, valuable biochemical composition. Therefore, it can be used in the manufacture of dessert products.

It is extremely important that the semi-finished cherrybeetroot puree contains significant amounts of biologically active substances, which allows to get the finished product for health purposes.

The main components of the dessert are semi-finished cherry-beetroot puree, water, white crystalline sugar, gelatin and citric acid.

During the experimental study and in order to determine the structural and mechanical parameters of the dessert, the amount of gelatin is calculated. Gelatin is added in an amount of $3 \%, 5 \%$, and $7 \%$ by weight of the semi-finished cherry-beetroot puree. The studies are carried out by uniaxial compression at a temperature of $20{ }^{\circ} \mathrm{C}$ and a load of $50 \mathrm{~g}$.

The obtained time dependences of the strain for a dessert with different amounts of gelatin show that the instantaneous elastic deformation of a sample with $3 \%$ gelatin is $5500 \cdot 10^{-5}$. For dessert samples with gelatin contents of $5 \%$ and $7 \%$, the instantaneous elastic deformation was $6000 \cdot 10^{-5}$ and $6800 \cdot 10^{-5}$, respectively. Given the organoleptic characteristics of the studied samples, a sample with a gelatin content of $3 \%$ has the best quality. Also, after removal of the load, the restoration of elastic deformation in all samples is observed. Based on the studies, a dessert formulation is developed on the basis of semi-finished cherry-beetroot puree, which is given in Table 3 . 
Table 3

Dessert recipe

\begin{tabular}{|l|c|c|}
\hline \multicolumn{1}{|c|}{ Raw materials } & Gross, g & Net, g \\
\hline semi-finished puree & 745 & 737 \\
\hline water & 208 & 208 \\
\hline sugar & 28 & 28 \\
\hline gelatin & 26 & 26 \\
\hline lemon acid & 1 & 1 \\
\hline output & - & 1000 \\
\hline
\end{tabular}

Based on the data obtained, a dessert production technology is developed that includes the following main steps: - preparation of semi-finished cherry-beetroot puree; - mixing mashed semi-finished product with sugar; - soaking gelatin with water in a ratio of 1:8, swelling at a temperature of $35-40{ }^{\circ} \mathrm{C}$ for $(15-20) \cdot 60 \mathrm{~s}$; - mixing the components of the dish from a gelatinous solution;

- filling in containers, dragging, storage of the finished dish.

Organoleptic and physico-chemical parameters of the finished dessert are also investigated, which are given in Table 4 and Table 5 , respectively.

Tahle 4

Organoleptic characteristics of jelly dessert

\begin{tabular}{|c|c|c|}
\hline \multirow{2}{*}{$\begin{array}{c}\text { Name } \\
\text { of indicator }\end{array}$} & \multicolumn{2}{|c|}{ Characteristics of sweet foods } \\
\cline { 2 - 3 } & $\begin{array}{c}\text { According to } \\
\text { the traditional recipe }\end{array}$ & $\begin{array}{c}\text { With semi-finished } \\
\text { cherry-beetroot puree }\end{array}$ \\
\hline Shape & $\begin{array}{c}\text { Correct, with a clear } \\
\text { contour }\end{array}$ & $\begin{array}{c}\text { Correct, with a clear contour, } \\
\text { no deformation }\end{array}$ \\
\hline $\begin{array}{c}\text { Taste } \\
\text { and smell }\end{array}$ & $\begin{array}{c}\text { Peculiar to sweet } \\
\text { dishes, without extra- } \\
\text { neous taste and smell }\end{array}$ & $\begin{array}{c}\text { Pronounced, due to the pre- } \\
\text { sence of mashed potatoes, with- } \\
\text { out extraneous taste and smell }\end{array}$ \\
\hline Colour & Dark yellow & Dark red \\
\hline Consistency & Jelly-like, not lingering & Jelly-like, not lingering \\
\hline $\begin{array}{c}\text { Surface } \\
\text { condition }\end{array}$ & Elastic & Elastic not sticky \\
\hline
\end{tabular}

According to the organoleptic characteristics, the finished dessert is characterized by the corresponding taste and aromatic characteristics: pleasant taste and smell, as well as the consistency, corresponds to the quality indicators of the products

Table 5

Physico-chemical characteristics of the finished dessert

\begin{tabular}{|c|c|}
\hline Quality level & Content, \% \\
\hline Mass fraction of solids & $14.11 \pm 0.30$ \\
\hline Mass fraction of sugars & $12.45 \pm 0.10$ \\
\hline Ash content & $0.11 \pm 0.001$ \\
\hline $\mathrm{pH}$ & 3.67 \\
\hline
\end{tabular}

The obtained physico-chemical parameters of the finished dessert meet the requirements of the current regulatory documentation for this type of product.

The content of biologically active substances with antioxidant and dexication properties in the finished dessert is also studied, which is: anthocyanins $-750 \mathrm{mg} / 100 \mathrm{~g}$, vitamin $\mathrm{C}-8 \mathrm{mg} / 100 \mathrm{~g}$, betalain $-45 \mathrm{mg} / 100 \mathrm{~g}$ and pectin substances - $1.8 \mathrm{~g} / 100 \mathrm{~g}$.

\section{Conclusions}

So, on the basis of the results obtained, it can be concluded that the use of cherry-beetroot puree is a semi-finished product in the technology of sweet dishes and desserts. An analysis of the physicochemical and organoleptic characteristics of the finished dessert shows that the use of gelatin in its formulation in an amount of $3 \%$ allows to obtain a product with good gelling properties. The presence of semi-finished cherry-beetroot puree in the dessert recipe enriches the product with biologically active substances of phenolic nature, vitamin $\mathrm{C}$ and pectin substances.

The presence of a significant amount of biologically active substances that have antioxidant properties, provide a healing and preventive effect of the dessert. The developed dessert is recommended for production in restaurant facilities.

\section{References}

1. Pyvovarov, P. P., Hrynchenko, O. O., Mykhailov, V. M., Ivanov, S. V., Kovalenko, A. A., Pyvovarov, Ye. P. et. al. (2011) Innovatsiini tekhnolohii vyrobnytstva kharchovoi produktsii masovoho spozhyvannia. Kharkiv: KhDUKhT, 444.

2. Kondratiuk, N. V., Pyvovarov, Ye. P., Neklesa, O. P. (2015) Naukovi aspekty tekhnolohii solodkykh strav z kapsulovanymy probiotychnymy mikroorhanizmamy. Kharkiv: KhDUKhT, 139.

3. Georgiev, Y., Ognyanov, M., Yanakieva, I., Kussovski, V., Kratchanova, M. (2012). Isolation, characterization and modification of citrus pectins. Journal of BioScience and Biotechnology, 1, 223-233.

4. Parekh, T., Patel, P., Subhash, R. (2008). Development of Probiotic and Synbiotic Chocolate Mousse: A Functional Food. Biotechnology(Faisalabad), 7 (4), 769-774. doi: http://doi.org/ 10.3923/biotech.2008.769.774

5. Verbeken, D., Thas, O., Dewettinck, K. (2004). Textural properties of gelled dairy desserts containing $\kappa$-carrageenan and starch. Food Hydrocolloids, 18 (5), 817-823. doi: http://doi.org/ 10.1016/j.foodhyd.2003.12.007

6. Sabadosh, H. O. (2016). Vplyv faktoriv na pinoutvorennia $\mathrm{v}$ tekhnolohii molochnykh desertiv z vykorystanniam karahinanu. Visnyk $N T U$ «KhPI», 29 (1209), 49-54.

7. Kravchuk, T. V. (2013). Vitaminizovani zheleini deserty z vykorystanniam antotsianovykh dobavok dlia zakladiv restorannoho hospodarstva. Kharchova nauka i tekhnolohiia, 1, 40-43.

8. Voznenko, M., Bondarenko, I., Yatsenko, B., Nyemirich, O. (2016). Technological aspects of the manufacture of whipped artichoke powder. Scientific Messenger of LNU of Veterinary Medicine and Biotechnologies. Series: Food Technologies, 18 (2), 32-36. doi: http://doi.org/10.15421/nvlvet6806

9. Ushchapovskyi, A. O., Ivchuk, N. P., Bashta, A. O. (2019) Pat. No. 131283 UA. Sposib otrymannia piure-napivfabrykatu iz buriaku stolovoho. MPK: (2016.01) A23L 19/10. No. 201807492; declareted: 04.07.2018; published: 10.01.2019, Bul. No. 1.

10. Koltunov, V. A. (2004). Yakist plodoovochevoi produktsii ta tekhnolohiia yii zberihannia Ch. 1. Yakist $i$ zberezhenist kartopli ta ovochiv. Kyiv: Kyivskyi natsionalnyi torhovelno-ekonomichnyi universytet, 568 .

11. Makarova, M. N., Makarov, M. H. (2005). Obzor metodov otsenky antyradykalnoi aktyvnosty pryrodnikh soedynenyi. Aktualnie problemi sozdanyia novikh lekarstvennikh preparatoz pryrodnoho proyskhozhdenyia. Saint Petersburg, 102-116.

12. Ushchapovskyi, A. O., Ivchuk, N. P., Bashta, A. O. (2018) Pat. No. 130860 UA. Piure-napiofabrykat vyshnevo-buriakovyi. MPK: (2016.01) A23L 21/10. No. u201807501; declareted: 04.07.2018; published: 26.12.2018, Bul. No. 24.

Ushchapozskyi Artem, Assistant, Postgraduate Student, Department of Hotel and Restaurant Business, National University of Food Technology, Kyiv, Ukraine, e-mail: ushchapovskyiao@gmail.com, ORCID: http://orcid.org/0000-0001-7853-5070

Ivchuk Nadiya, PhD, Associate Professor, Department of Technology of Health Products, National University of Food Technology, Kyiv, Ukraine, e-mail: vira.nadija@gmail.com, ORCID: http://orcid.org/ 0000-0001-6140-1703 